\title{
Article \\ Energy Saving in Trigeneration Plant for Food Industries ${ }^{\dagger}$
}

\author{
Andrii Radchenko ${ }^{1}$, Mykola Radchenko ${ }^{1, *}{ }^{(0)}$, Dariusz Mikielewicz ${ }^{2}{ }^{(D}$, Anatoliy Pavlenko ${ }^{3}{ }^{(}$, \\ Roman Radchenko ${ }^{1}$ and Serhiy Forduy ${ }^{4}$
}

1 Machinebuilding Institute, Admiral Makarov National University of Shipbuilding, Heroes of Ukraine Avenue 9, 54025 Mykolayiv, Ukraine; andrad1978@gmail.com (A.R.); ronirad19@gmail.com (R.R.)

2 Faculty of Mechanical Engineering and Ship Technology, Gdansk University of Technology, 80-233 Gdansk, Poland; dariusz.mikielewicz@pg.edu.pl

3 Department of Building Physics and Renewable Energy, Kielce University of Technology, Al. Thousand Years of Polish State 7, 25-314 Kielce, Poland; apavlenko@tu.kielce.pl

4 PepsiCo, Inc., 01010 Kyiv, Ukraine; serhiy.forduy@pepsico.com

* Correspondence: nirad50@gmail.com

+ This paper is an extended version of our paper published in 2021 MPSU-2021, E3S Web of Conferences 323,00029 .

Citation: Radchenko, A.; Radchenko, M.; Mikielewicz, D.; Pavlenko, A.; Radchenko, R.; Forduy, S. Energy Saving in Trigeneration Plant for Food Industries. Energies 2022, 15 1163. https://doi.org/10.3390/ en15031163

Academic Editors: Patrick Phelan and Chanwoo Park

Received: 7 December 2021

Accepted: 30 January 2022

Published: 4 February 2022

Publisher's Note: MDPI stays neutral with regard to jurisdictional claims in published maps and institutional affiliations.

Copyright: (C) 2022 by the authors. Licensee MDPI, Basel, Switzerland. This article is an open access article distributed under the terms and conditions of the Creative Commons Attribution (CC BY) license (https:// creativecommons.org/licenses/by/ $4.0 /)$.

\begin{abstract}
The trigeneration plants for combined cooling, heating, and electricity supply, or integrated energy systems (IES), are mostly based on gas reciprocating engines. The fuel efficiency of gas reciprocating engines depends essentially on air intake temperatures. The transformation of the heat removed from the combustion engines into refrigeration is generally conducted by absorption lithium-bromide chillers (ACh). The peculiarity of refrigeration generation in food technologies is the use of chilled water of about $12{ }^{\circ} \mathrm{C}$ instead of $7{ }^{\circ} \mathrm{C}$ as the most typical for ACh. This leads to a considerable cooling potential not realized by ACh that could be used for cooling the engine intake air. A refrigerant ejector chiller (ECh) is the simplest in design, cheap, and can be applied as the low-temperature stage of a two-stage absorption-ejector chiller (AECh) to provide engine intake air cooling and increase engine fuel efficiency as result. The monitoring data on gas engine fuel consumption and power were analyzed in order to evaluate the effect of gas engine cyclic air cooling.
\end{abstract}

Keywords: trigeneration plant; gas reciprocating engine; engine cyclic air; two-stage cooling

\section{Introduction}

Gas engines (GE) [1,2] are widely applied as drive engines in trigeneration systems, or integrated energy systems (IES), for combined cooling, heating, and power (CCHP) [3,4]. The thermodynamic efficiency of GE falls with increasing inlet air temperature: electric power drops and specific fuel consumption grows. The heat released from GE is mostly converted to refrigeration by absorption lithium-bromide chillers ( $\mathrm{ACh}$ ) and used for technological needs. So it is quite reasonable to use the refrigeration generated by $\mathrm{ACh}$ for engine inlet air cooling (EIAC), i.e., for in-cycle trigeneration [5,6]. In addition to enhancing engine fuel efficiency, this enables prolonging the duration of efficient trigeneration plant operation too $[7,8]$. It is of great importance that the refrigeration demands for technological duties have a periodic character as a rule.

In integrated energy systems for food technologies, chilled water with a temperature of about $12{ }^{\circ} \mathrm{C}$ is mostly used; this is higher than the $7{ }^{\circ} \mathrm{C}$ characterized for a typical $\mathrm{ACh}[9,10]$. Thus, a significant cooling potential and the corresponding heat released from GE remains and is not realized by ACh. A refrigerant ejector chiller (ECh) might be applied as the low-temperature stage of a two-stage absorption-ejector chiller (AECh) to use the excessive thermal potential for engine intake air cooling that leads to enhanced engine fuel efficiency [11,12].

In a typical IES, all the ambient air coming into the engine room is cooled in the central conditioner [4]. Because of heat influx from the engine room surroundings to the air stream 
sucked by the engine turbocharger (TC), the temperature of the air at the suction of the turbocharger is increased and the required cooling capacity is enlarged.

Many pieces of research are aimed at enhancing the operational efficiency of trigeneration plants $[13,14]$ based on combustion engines and designed for technological needs $[15,16]$, space conditioning $[17,18]$, and other duties. A lot of them are devoted to improving the fuel efficiency of engines $[19,20]$ through cyclic air cooling in waste heat recovery chillers $[21,22]$. The $\mathrm{ACh}$ is mostly used for chilling air to about $15{ }^{\circ} \mathrm{C}$ with a high coefficient of performance (COP) of 0.7 to $0.8[23,24]$. The thermopressors $[25,26]$ and ejector chillers $(\mathrm{ECh})[27,28]$ are the simplest in design, generally consisting of heat exchangers $[29,30]$. The ejector chillers are able to cool the air down to $10^{\circ} \mathrm{C}$ and lower, but with a lowered COP of 0.2 to 0.3 .

The efficiency of chillers and cooling systems on the whole can be enhanced by an intensification of heat transfer in evaporators and condensers $[31,32]$ by the application of advanced circulation contours $[33,34]$ using the cooling potential of evaporated water [35,36], exhaust heat potential [37,38], and alternative fuels [39,40]. They enable deep exhaust heat utilization $[41,42]$ with low temperature condensation $[43,44]$. Such technologies provide for the increasing heat potential to be converted by heat recovery chillers $[45,46]$ for engine cyclic air cooling [47,48]. Many environment-friendly and waste heat conserving innovations might be applied in EIAC [49,50], including transport applications [51,52].

A lot of control optimization [53,54] and regulation [55,56] methods are used to optimize the thermal loads on air cooling systems in order to match actual varying climatic conditions and gain a maximum effect due to cooling. With this, in addition to fundamental exergy and exergoeconomic analysis [57], the widespread methods for estimating the effect gained due to cooling air modified for simplified calculations were developed [58-60].

The majority of well-known concepts to enhance the efficiency of trigeneration systems are focused on the engine out-cycle application of refrigeration and based on conventional heat conversion in ACh. A realization of the engine in-cycle concept of trigeneration based on EIAC would provide a widespread application of trigeneration even for the lack of cooling needs.

The application of combined cooling, heat, and power (CCHP) generation, or trigeneration, enables the COP to be increased by about $50 \%$ compared with their separate generation and practically twice increased yearly operation time compared with cogeneration; therefore, they are very prosperous in food industries to substitute vapor compression refrigeration with an electrically driven compressor.

The results of similar studies previously published issued from the most typical operation of $\mathrm{ACh}$ for the production of chilled water with a temperature of about $7^{\circ} \mathrm{C}$, but not the $12{ }^{\circ} \mathrm{C}$ required for technological needs in juice and other similar food industries where the cooling potential not realized by an $\mathrm{ACh}$ is considerably higher.

A new concept based on combined two-stage EIAC in ACh and ECh would enable the stabilization of the engine intake air at a low temperature. It could be realized by using chilled water from an ACh as a coolant in a high-temperature engine inlet air cooler and boiling refrigerant fed from an ECh-in a low-temperature air cooler [61].

The purpose of this research is to increase the fuel efficiency of a gas engine by combining two-stage inlet air cooling and estimate engine fuel efficiency enhancement on the basis of monitoring data.

\section{Materials and Methods}

\subsection{General Assumptions and Hypothesis}

So far as proposed, AECh systems are the advanced versions of traditional basic ACh systems, the economic comparison with the last might be done taking by into account only the cost of extra heat exchangers of ECh (refrigerant evaporator-air cooler, refrigerant condenser, refrigerant pump, and ejector) with an unchanged maintenance cost, personnel, etc. Because of variations in the cost of heat exchangers of different manufacturers and fuel especially, the economic analysis is to be conducted for the concrete case. Thus, the 
proposed method of designing the ACh system focuses on providing just initial basic data as rational technical characteristics further complicate a detailed economic analysis.

The hypotheses accepted to prove novel approaches to the principles of the proposed innovative AECh engine intake air cooling system operation are the following.

The heat influx to the engine room from heat exchangers (HExch) for the production of hot water through the removing of heat from gas engine cooling water, oil, scavenge air, exhaust gas, and heat influx to the engine room from surroundings causes, by insolation and heat transfer, a considerably (twice and more) increased thermal load on the typical engine intake air cooling (EIAC) system with intake air sucked by turbocharger from the engine room. Issuing from this point, it is not reasonable to cool all the ambient air coming into the engine room as in a typical central air conditioner, but just the engine turbocharger intake air or increasing its volume in account with the alternator cooling needs.

The assumptions adopted for the comparative analysis of the fuel efficiency of the basic types and developed EIAC systems are as follows:

The lowest temperature of air cooled in the ACh of a basic EIAC system is assumed to be $t_{\mathrm{a} 2}=20^{\circ} \mathrm{C}$ and limited by the minimum temperature difference of $8^{\circ} \mathrm{C}$ between cooled air and chilled water, leaving the $\mathrm{ACh}$ at $\mathrm{t}_{\mathrm{w}}=12{ }^{\circ} \mathrm{C}$ (water at the inlet of air cooler): $\mathrm{t}_{\mathrm{a} 2}=$ $\mathrm{t}_{\mathrm{w}}+8{ }^{\circ} \mathrm{C}$.

In the case of using a refrigerant as a coolant in the low-temperature stage of the two-stage air cooler, the temperature difference between the air being cooled and boiling refrigerant is lower, 4 or $5^{\circ} \mathrm{C}$. Proceeding from this, the values of minimum temperature $\mathrm{t}_{\mathrm{a} 2}$ of air cooled in refrigerant chiller might be $10{ }^{\circ} \mathrm{C}$ and lower: $\mathrm{t}_{\mathrm{a} 2}=\mathrm{t}_{0}+(4 \text { or } 5)^{\circ} \mathrm{C}$.

The annual fuel reduction $\Sigma \mathrm{B}$ is used as a primary criterion.

\subsection{Calculation Procedure}

The annual fuel reduction $\Sigma \mathrm{B}$ gained due to cooling gas engine intake air at varying loading on the EIAC system in response to actual climatic conditions was calculated by summarizing current values of fuel reduction increments through the "hour-by-hour" procedure.

The real input data of on-site actual ambient air temperature $t_{a m b}$ were taken by using the program "meteomanz".

The current values of total fuel reduction per an hour were

$$
\mathrm{B}=\Delta \mathrm{t} \cdot\left(\Delta \mathrm{b}_{\mathrm{e}} / \Delta \mathrm{t}\right) \cdot \mathrm{P}_{\mathrm{e}}
$$

where a specific fuel reduction (for $1 \mathrm{~kW}$ gas engine power output) for every $1{ }^{\circ} \mathrm{C}$ drop in engine intake air temperature is $\Delta \mathrm{b}_{\mathrm{e}} / \Delta \mathrm{t}$, engine intake air temperature depression in the air cooler is $\Delta t=t_{a 1}-t_{a 2}$, and engine power output $P_{e}$, is taken according to monitoring data.

The annual fuel reduction was

$$
\Sigma \mathrm{B}=\Sigma \Delta \mathrm{t} \cdot \tau\left(\Delta \mathrm{b}_{\mathrm{e}} / \Delta \mathrm{t}\right) \cdot \mathrm{P}_{\mathrm{e}}
$$

The values of annual emission reduction were calculated proceeding from a reduction in $\mathrm{CO}_{2}$ emissions by $428.7 \mathrm{~g}$ and $\mathrm{NO}_{\mathrm{X}}$ by $2.78 \mathrm{~g}$ for each $1 \mathrm{~m}^{3}$ gas fuel reduction [62].

The heat of hot water (with a temperature of about $90^{\circ} \mathrm{C}$ ) produced by a cogenerative gas engine module, converted by the $\mathrm{ACh}$ of a simple cycle is limited by the hot water temperature drop, not more than $15{ }^{\circ} \mathrm{C}$, in order to keep the COP of the ACh at a high level of about 0.7. As a result, the temperature of heating water at the outlet of the ACh is not lower than $75^{\circ} \mathrm{C}$. Meanwhile, the temperature of return cooled water at the inlet of the cogenerative gas engine module, used as a coolant to remove the heat from the engine, should not be higher than $70^{\circ} \mathrm{C}$ in order to keep the engine at a safe thermal level. The excess of return warm water heat is traditionally extracted into the atmosphere by an emergency radiator (Figure 1). Thus, about $25 \%$ of hot water heat released from the gas 
engine can be converted into additional refrigeration capacity by refrigerant ECh as the simplest in design for further deeper cooling engine intake air precooled in ACh.

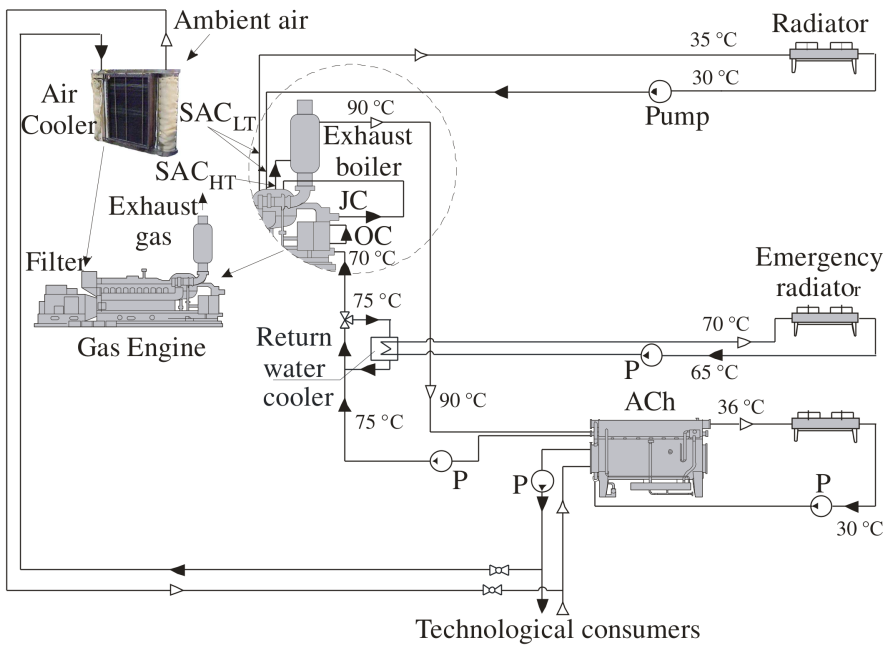

Figure 1. A schema of a typical system of cogenerative gas engine heat conversion by ACh with engine intake air cooling in the air cooler of the central conditioner by chilled water from the $\mathrm{ACh}$ : OC-oil cooler; JC-jacket cooler; $\mathrm{SAC}_{\mathrm{LT}}$ and $\mathrm{SAC}_{\mathrm{HT}}$-low- and high-temperature scavenge air coolers.

The efficiency of gas engine inlet air cooling is investigated for the trigeneration plant of "Sandora"-"PepsiCo Ukraine" (Mykolayiv, Ukraine). The trigeneration plant is equipped with two Jenbacher gas engines JMS 420 GS-N.LC (rated electric power $\mathrm{P}_{\text {eISO }}=$ $1400 \mathrm{~kW}$ and heat $\mathrm{Q}_{\mathrm{h}}=1500 \mathrm{~kW}$ ) and ACh AR-D500L2 Century (Figure 2).

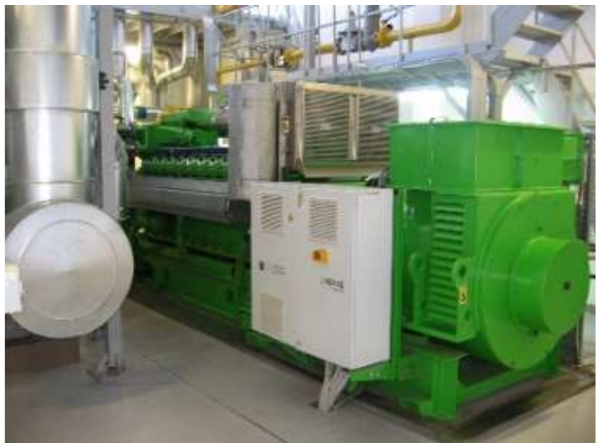

(a)

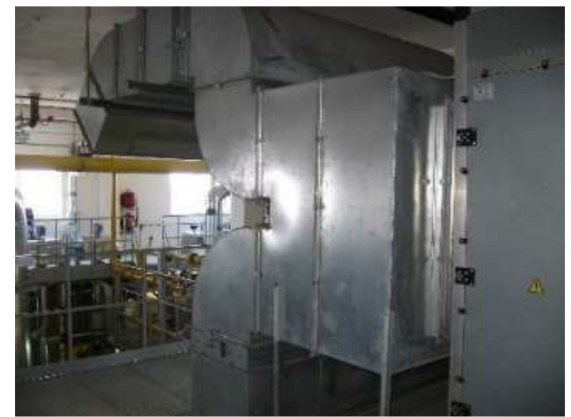

(c)

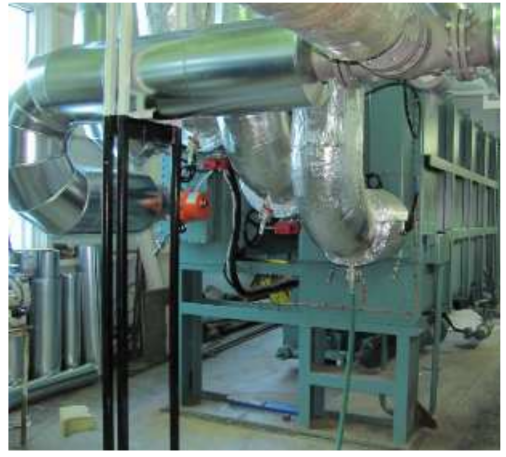

(b)

Figure 2. Gas engine module JMS GE Jenbacher (a), absorption chiller AR-D500L2 (b), and central conditioner for engine room incoming air cooling (c).

A typical scheme of gas engine inlet air cooling system is presented in Figure 3. 


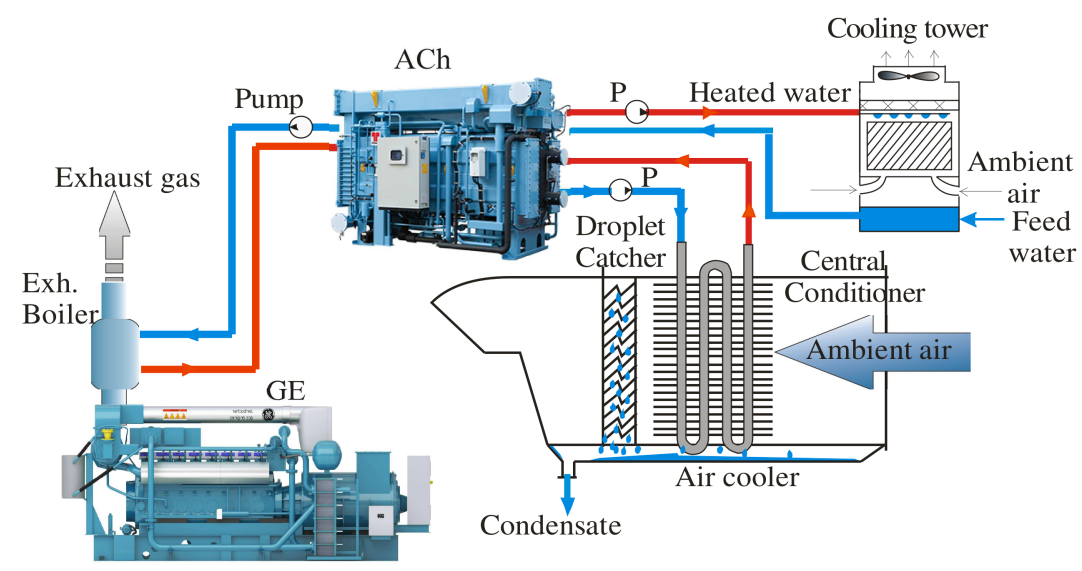

Figure 3. A scheme of a typical system of gas engine inlet air cooling in the central conditioner by chilled water from an ACh.

Because of the heat influx to cooled air stems from the engine room environment, the temperature of the air $t_{\text {in }}$ at the inlet of the engine is higher than its value $t_{\mathrm{HT}}$ at the outlet of high-temperature air cooler $\mathrm{AC}_{\mathrm{HT}}$ of the central conditioner by air temperature increment $\Delta t_{\mathrm{ER}}$ caused by heat influx: $\mathrm{t}_{\mathrm{in}}=\mathrm{t}_{\mathrm{HT}}+\Delta \mathrm{t}_{\mathrm{ER}}$ (Figure 4$)$.

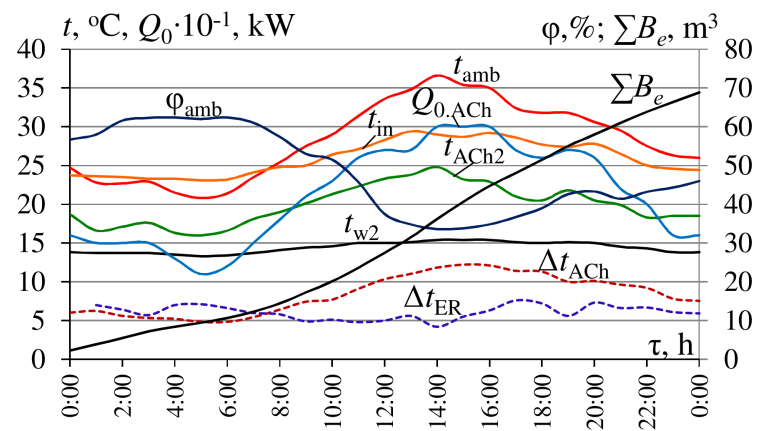

Figure 4. Daily variations in temperature $t_{\mathrm{amb}}$ and relative humidity $\varphi_{\mathrm{amb}}$ of ambient air, temperature of air at the gas engine inlet $t_{\mathrm{in}}$, and at the high-temperature air cooler outlet $t_{\mathrm{ACh} 2}=t_{\mathrm{HT}}, \Delta \mathrm{t}_{\mathrm{ACh}}=$ $\Delta \mathrm{t}_{\mathrm{HT}}=\mathrm{t}_{\mathrm{amb}}-\mathrm{t}_{\mathrm{HT}} ; \Delta \mathrm{t}_{\mathrm{ER}}=\mathrm{t}_{\mathrm{in}}-\mathrm{t}_{\mathrm{HT}}$.

A considerably increased temperature of the air at the inlet of engine $t_{\text {in }}$ proves a non-effective operation of the conventional EIAC system by chilled water from an ACh with a temperature of $12{ }^{\circ} \mathrm{C}$.

\section{Results}

In order to evaluate the effect of GE inlet air two-stage cooling, compared with conventional conditioning all the ambient air coming into the engine room, the data of gas engine JMS 420 GS-N.L fuel efficiency monitoring were used.

The results of monitoring a gas engine fuel efficiency were presented in the form of data sets on the dependence of fuel consumption $B_{e}=f\left(t_{i n}\right)$, power output $P_{e}=f\left(t_{i n}\right)$, and specific fuel consumption $b_{e}=B_{f} / P_{e}$ upon the air temperatures $t_{i n}$ at the inlet of the engine turbocharger. A method for processing the monitoring data on fuel consumption and power output of the gas engine was developed [11,61].

The goal of processing the monitoring data sets $P_{e}=f\left(t_{\text {in }}\right), B_{e}=f\left(t_{\text {in }}\right)$, and $b_{e}=f\left(t_{\text {in }}\right)$ was to calculate the value of the change in specific fuel consumption $\Delta \mathrm{b}_{\mathrm{e}}$ caused by the change in the engine inlet air temperature $\mathrm{t}_{\text {in }}$ by $1{ }^{\circ} \mathrm{C}$, as $\Delta \mathrm{b}_{\mathrm{e}} / \Delta \mathrm{t}_{\text {in }}$, to estimate the fuel-saving due to applying the advanced two-stage air cooling [48,61].

The daily variation of volume gas consumption $B_{e}$ and electric power $P_{e}$ of engine JMS 420 GS based on monitoring data are presented in Figures 5-7. 


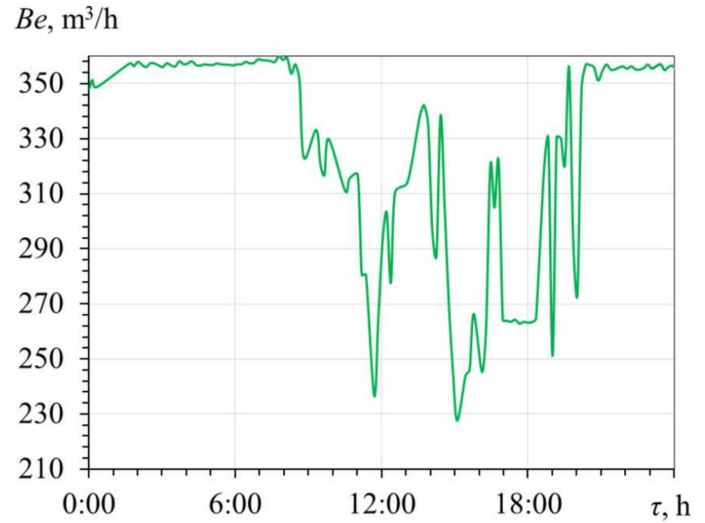

(a)

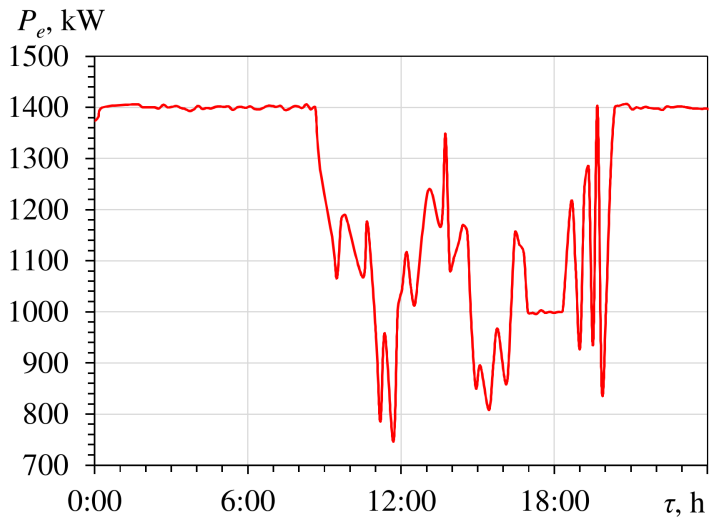

(b)

Figure 5. Daily variation of volume gas consumption $B_{e}(a)$ and electric power $P_{e}(\mathbf{b})$ of the gas engine against time $\tau$.

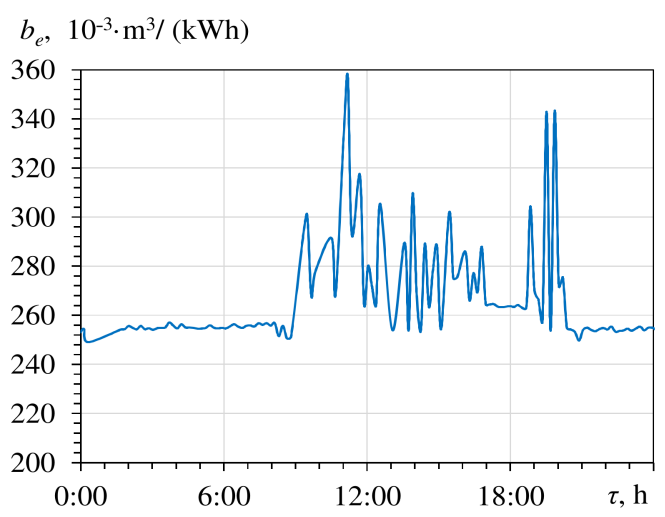

(a) $b_{e}, 10^{-3} \mathrm{~m}^{3} /(\mathrm{kWh})$

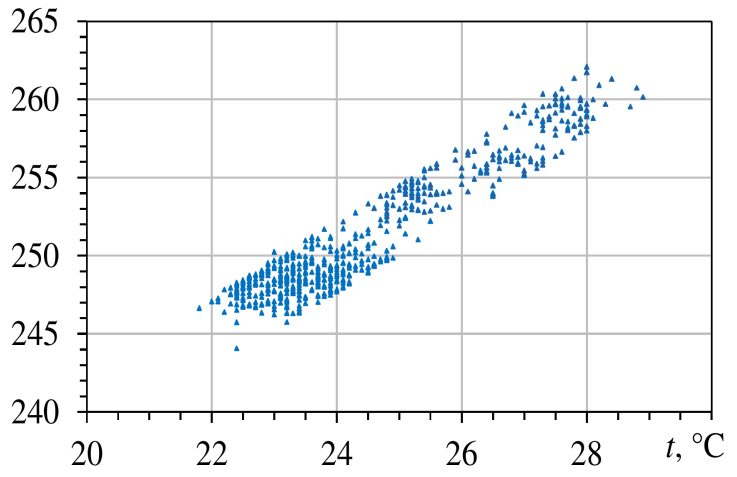

(b)

Figure 6. Specific volume gas consumption $b_{e}$ aa a daily variation against time $\tau(\mathbf{a})$ and inlet air temperature $\mathbf{t}(\mathbf{b})$.

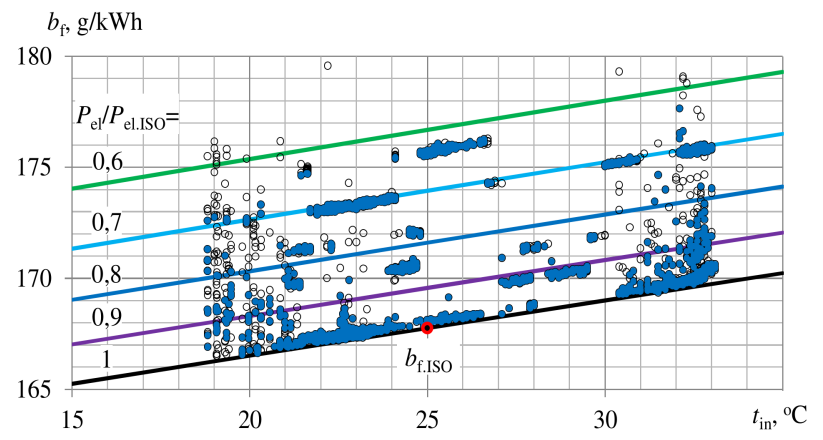

Figure 7. Variation of mass-specific fuel consumption $b_{\mathrm{f}}$ against inlet air temperature $t_{\text {in }}$ at various loads $\mathrm{P}_{\mathrm{el}} / \mathrm{P}_{\mathrm{el} . \mathrm{ISO}}, \mathrm{P}_{\mathrm{el}}$ - electrical power as monitored data; $\mathrm{P}_{\mathrm{el} . I S O}$-rated electrical power at ISO ambient air parameters: $\mathrm{t}_{\mathrm{amb}}=25^{\circ} \mathrm{C}$, and relative humidity $\varphi_{\mathrm{amb}}=30 \%$.

During hot summer days at time interval $\tau=9 \ldots 20 \mathrm{~h}$ the ambient air temperatures are increased: $t_{a m b}=30 \ldots 35^{\circ} \mathrm{C}$, which makes it impossible to cool a charged gas-air mixture by the radiator to an appropriate level when the temperature is about $40{ }^{\circ} \mathrm{C}$. This leads to an automatically decreasing gas supply to the engine and power output accordingly (Figure 5).

Performance of the gas engine at a raised intake air temperature $t_{\text {in }}(\tau=9 \ldots 20 \mathrm{~h})$ is followed by an increase in specific gas consumption $b_{\mathrm{e}}$ by $(20 \ldots 30) \times 10^{-3} \mathrm{~m}^{3} /(\mathrm{kWh})$ 
(Figure 5a), i.e., $8 \ldots 12 \%$ compared with engine full loading at ambient air temperatures $t_{a m b}$ and corresponding $t_{\text {in }}$ lower than $25^{\circ} \mathrm{C}(\tau=2 \ldots 9 \mathrm{~h})$.

As Figure 6 shows, arising intake air temperature $t$ causes a considerable increase in specific volume gas consumption $b_{\mathrm{e}}$.

As Figure 7 shows, with decreasing engine inlet air temperatures $t_{\text {in }}$ the mass-specific fuel consumption $b_{f}$ reduces by 0.25 to $0.27 \mathrm{~g} /(\mathrm{kWh})$ for $1{ }^{\circ} \mathrm{C}$ drop of engine inlet air temperature $\Delta \mathrm{t}_{\text {in }}=1^{\circ} \mathrm{C}$.

A deviation of calculated values of mass-specific fuel consumption $b_{\text {f.calc }}$ from monitoring data $\mathrm{b}_{\mathrm{f} \text {.monit }}$ is within the range of $10 \%$ with a probability of $95 \%$ and within the range of $5 \%$ with a probability of $65 \%$ (Figure 8 ).

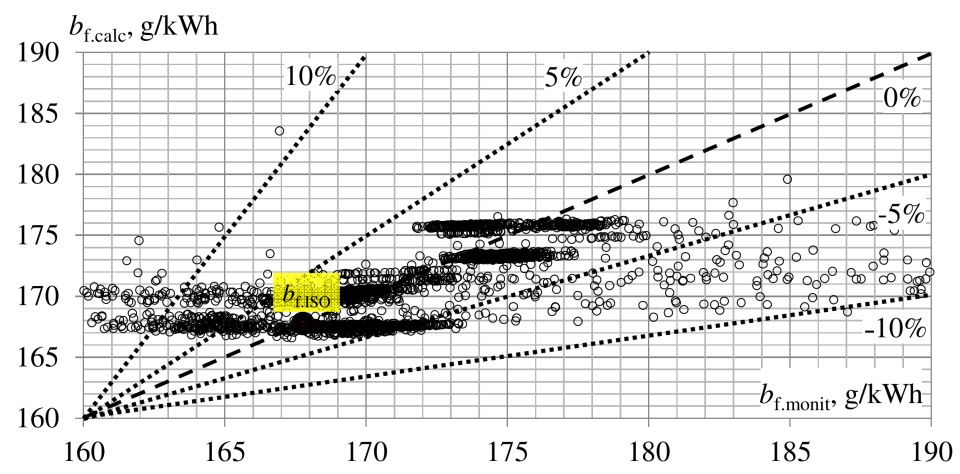

Figure 8. Mass specific fuel consumption calculated values $b_{\text {f.calc }}$ against monitoring data $b_{\text {f.monit }}$.

Issuing from a reduction in specific fuel consumption $b_{f}$ with decreasing engine inlet air temperatures $t_{\text {in, }}$ a concept of addition inlet air subcooling compared with its typical cooling by chilled water with a temperature of about $12{ }^{\circ} \mathrm{C}$ in $\mathrm{ACh}$, used for technological cooling needs, is developed (Figure 9).

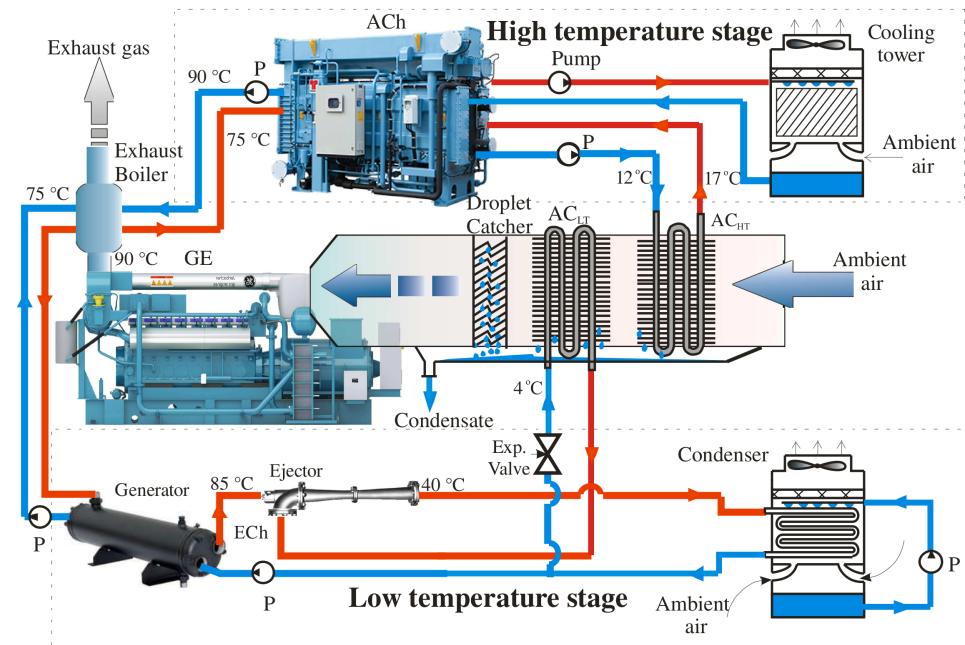

Figure 9. A two-stage absorption-ejector (AECh) system for chilling engine inlet air: $A C_{\mathrm{HT}}$ and $\mathrm{AC}_{\mathrm{LT}}$ - high- and low-temperature air coolers; $\mathrm{P}$ - pump.

The calculation results of thermal loads $\mathrm{Q}_{0 . \mathrm{HT}}$ and $\mathrm{Q}_{0 . \mathrm{LT}}$ on high- and low-temperature air coolers and $\mathrm{Q}_{0 . \mathrm{AC}}$ on the whole two-stage air cooler, based on the monitored air temperatures at the turbocharger inlet $t_{\text {in }}$, indicates current specific fuel consumption decreases $\Delta \mathrm{b}_{\mathrm{e}}$ as well as daily summarized volume gas-saving $\Sigma \mathrm{B}_{\mathrm{e}}$ due to engine inlet air cooling in high-temperature cooler $\mathrm{AC}_{\mathrm{HT}}$ by $\mathrm{ACh}$ and low-temperature cooler $\mathrm{AC}_{\mathrm{LT}}$ by $\mathrm{ECh}$. The overall gas-saving results for two-stage AECh are presented in Figure 10. 


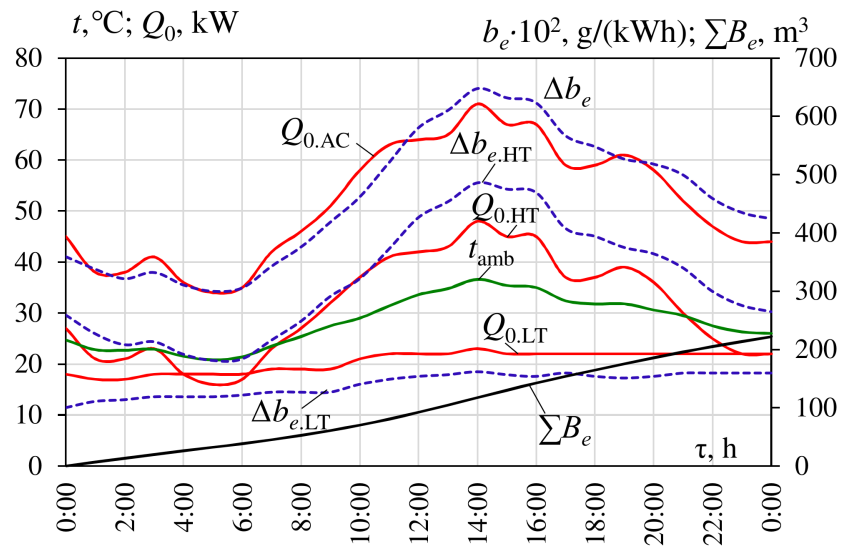

Figure 10. Daily variation of thermal loads $Q_{0 . H T}$ and $Q_{0 . L T}$ on high- and low-temperature air coolers and $\mathrm{Q}_{0 . \mathrm{AC}}$ on the whole two-stage air cooler; $\mathrm{Q}_{0 . \mathrm{HT}}$ and decreases of specific fuel consumption $\Delta \mathrm{b}_{\mathrm{e} . \mathrm{HT}}, \Delta \mathrm{b}_{\mathrm{e} . \mathrm{LT}}, \Delta \mathrm{b}_{\mathrm{e}}$, accordingly, and summarized volume gas-saving $\Sigma \mathrm{B}_{\mathrm{e}}$ (Mykolayiv region, south of Ukraine, 2017).

Thus, the developed combined two-stage engine inlet air cooling system enables the operation of GE at a practically stabilized low sucked air temperatures at variable actual climatic conditions. This results in a reduction of specific fuel consumption by about 3 to $5 \mathrm{~g} /(\mathrm{kWh})$ or in $3 \%$ at raised ambient air temperatures $t_{\mathrm{amb}}$.

\section{Discussion}

The application of a developed combined two-stage AECh engine inlet air cooling system enables the engine to operate at a practically stabilized low sucked air temperature at varying climatic conditions that result in monthly $\mathrm{B}$ and annual $\Sigma \mathrm{B}$ reduction of fuel consumption (Figure 11). With this, the annual fuel reduction $\Sigma \mathrm{B}$ is used as a primary criterion.

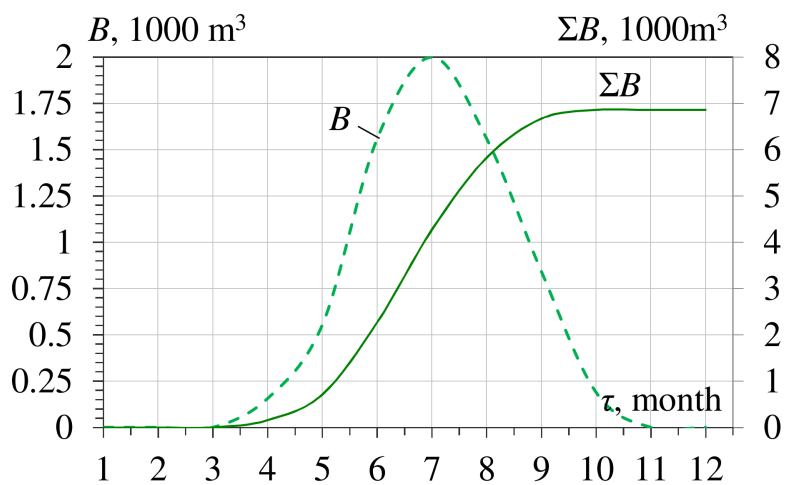

Figure 11. Monthly B and annual fuel saving $\Sigma$ B for gas engine JMS 420 GS due to inlet air cooling in AECh (Mykolayiv region, south of Ukraine, 2017).

The annual fuel reduction $\Sigma \mathrm{B}$ gained due to cooling gas engine intake air at varying loading on the EIAC system in response to actual climatic conditions was calculated by summarizing the current values of fuel reduction increments through the "hour-by-hour" procedure.

The calculation results of the ecological effect due to engine intake air cooling in AECh in 2017 are presented in Figure 12. The values of the reduction in carbon dioxide $\Sigma \mathrm{CO}_{2}$ emissions for GE (power output 1.4 MW) due to intake air cooling in AECh are presented in Figure 12a and the reduction in $\Sigma \mathrm{NO}_{\mathrm{X}}$ emissions in Figure 12b. 


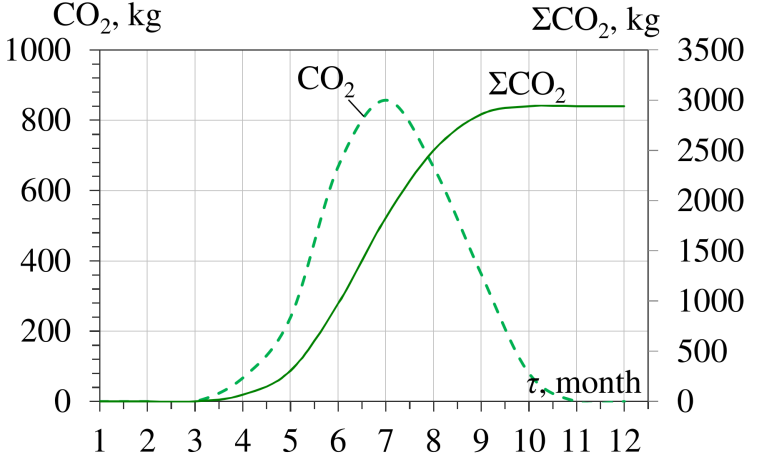

(a)

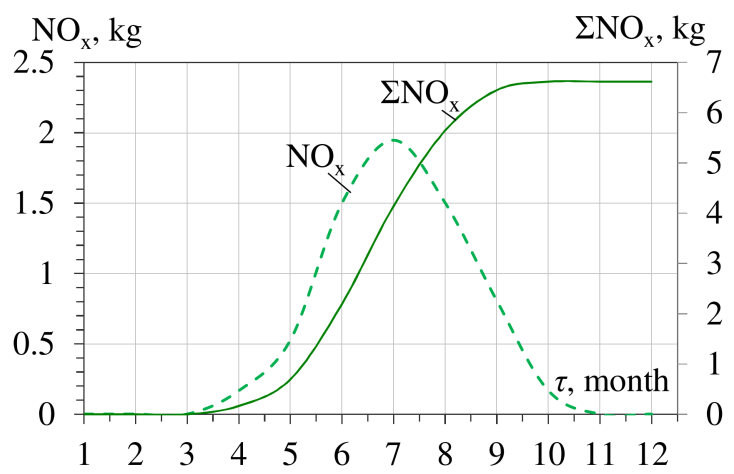

(b)

Figure 12. Monthly $\mathrm{CO}_{2}$ and annual $\Sigma \mathrm{CO}_{2}(\mathbf{a})$ and monthly $\mathrm{NO}_{\mathrm{x}}$ and annual $\Sigma \mathrm{NO}_{\mathrm{x}}(\mathbf{b})$ emission reduction due to engine inlet air cooling in AECh (Mykolayiv, southern Ukraine, 2017).

The values of the annual emission reduction were calculated issuing from a reduction in $\mathrm{CO}_{2}$ emissions by $428.7 \mathrm{~g}$ and $\mathrm{NO}_{\mathrm{X}}$ by $2.78 \mathrm{~g}$ for each $1 \mathrm{~m}^{3}$ gas fuel reduction [62].

The system of TIAC in ACh and ECh consequently provides about $50 \%$ additional annual fuel saving compared with traditional air cooling in ACh for temperate climatic conditions (southern Ukraine) (Figure 13).

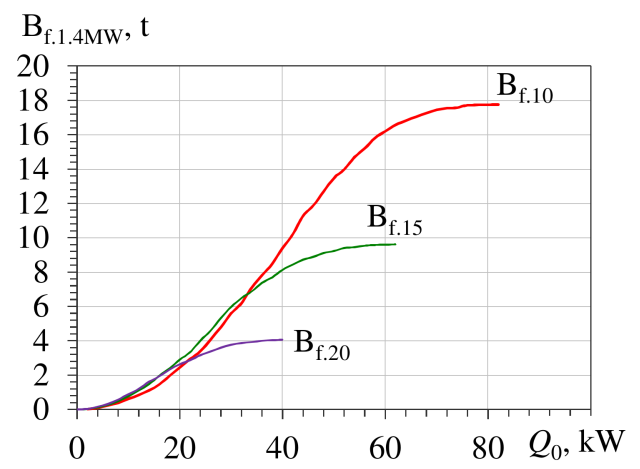

Figure 13. Annual fuel-saving $\Sigma \mathrm{B} \mathrm{B}_{\mathrm{f}}$ versus design cooling capacities $\mathrm{Q}_{0}$ of chillers for engine intake air temperatures at 15 and $20^{\circ} \mathrm{C}$ in ACh and $10{ }^{\circ} \mathrm{C}$ in AECh (Mykolayiv region, south of Ukraine, 2017).

Due to minimizing the heat influx of turbocharger suctioned air from the environment, the two-stage air cooling system enables engine performance at stabilized low intake air temperatures at varying climatic conditions.

So far as the proposed, the AECh system is the advanced version of the traditional basic ACh system. The economic comparison with the former might be done taking into account only the cost of extra heat exchangers of ECh (refrigerant evaporator-air cooler, refrigerant condenser, and ejector) with an unchanged maintenance cost, personnel, etc.

As a basic variant, the GE JMS $420 \mathrm{GS}$ of the power output of $1.4 \mathrm{MW}$ and air mass flow rate $\mathrm{G}_{\mathrm{a}}=2 \mathrm{~kg} / \mathrm{s}$ is accepted. According to Figure 10, $\mathrm{Q}_{0.10}=80 \mathrm{~kW}$ for EIAC system with $\mathrm{AECh}$ and $\mathrm{Q}_{0.15}=60 \mathrm{~kW}$ for the traditional ACh with corresponding annual fuel reduction $\sum \mathrm{B}_{10}=17.5 \mathrm{t}$ and $\sum \mathrm{B}_{15}=9.4 \mathrm{t}$. Proceeding from these data, the value of the total cooling load on low-temperature $\mathrm{ECh} \mathrm{Q}_{0.10-15}=\mathrm{Q}_{0.10}-\mathrm{Q}_{0.15}$, i.e., $20 \mathrm{~kW}$, provides additional annual fuel reduction $\sum \mathrm{B}_{10-15}=\sum \mathrm{B}_{10}-\sum \mathrm{B}_{15}$ of about $8 \mathrm{t}$ as compared with the traditional ACh system. Thus, the cooling capacity of a refrigerant evaporator-air cooler of ECh $Q_{0.10-15}=20 \mathrm{~kW}$ and of refrigerant condenser $Q_{\text {condenser }}=Q_{0.10-15}(1+C O P)$, i.e., about $26 \mathrm{~kW}$, where COP of ECh can be accepted as 0.3. Taking into account the cost of extra heat exchangers of ECh (about $\$ 4420$ according to [63]) and including its additional $10 \%$ increase for ejectors and $10 \%$ for mounting, the cost of additional equipment of ECh 
is about $\$ 5300$. On the other hand, the cost of gas fuel annually saved is about $\$ 8000$ (proceeding from the price of gas $\$ 1000$ per $1000 \mathrm{~m}^{3}$ ) and the payback period is less than a year.

The application of a cheap ECh as a low-temperature stage of AECh is quite reasonable in contrast to applying the additional (quite expensive) ACh that is able to produce chilled water of about $7^{\circ} \mathrm{C}$ and was able to cool air lower than $15^{\circ} \mathrm{C}$. Additionally, the ECh cools air to $10{ }^{\circ} \mathrm{C}$ and has about a $50 \%$ additional annual fuel savings compared with cooling the air to $15^{\circ} \mathrm{C}$ with an ACh (Figure 13). Furthermore, the ECh with refrigerant boiling at a temperature lower than $5{ }^{\circ} \mathrm{C}$ might be used to produce chilled water accumulated at decreased ambient air temperature and the thermal load on the EIAC system to cover peaked cooling needs.

Because of the fluctuations in the cost of heat exchangers of different manufacturers and the price of the gas fuel especially, the economic analysis is to be conducted for the concrete case. Thus, the considered method of designing focuses to provide just initial basic data as rational technical characteristics for further complicated detailed economic analysis.

\section{Conclusions}

An analysis of monitoring data on the fuel consumption of gas engine JMS 420 GSN.L has proved the typical cooling of the ambient air incoming into the engine room in ACh with a chilled water temperature of about $12{ }^{\circ} \mathrm{C}$, required for technological duties, is inefficient.

A novel concept of two-stage engine inlet air cooling in trigeneration IES for food industries is proposed which issues from the monitoring data on the reduction in specific fuel consumption with lowering the temperatures of air at the inlet of the engine. An engine intake air cooling (EIAC) system is developed that includes an $\mathrm{ACh}$ as a high-temperature stage for cooling ambient air to about $20^{\circ} \mathrm{C}$ by chilled water of about $12{ }^{\circ} \mathrm{C}$ (used for technological needs) and refrigerant ejector chiller as the second low-temperature stage of EIAC that uses a cooling potential (not realized by Ach) for further cooling of the air to about $10{ }^{\circ} \mathrm{C}$ by boiling refrigerant.

A refrigerant ejector chiller (ECh) is the simplest in design, cheap and can be applied as the low-temperature stage of a two-stage absorption-ejector chiller (AECh) to provide engine intake air cooling and increase engine fuel efficiency as result.

The combined two-stage waste heat recovery cooling system developed is practically independent of load modes of technological cold consumers due to using a cooling potential not realized by an ACh and enables a high fuel efficiency of GE - reduction of specific fuel consumption of GE JMS 420 GS by 3 to $5 \mathrm{~g} /(\mathrm{kWh})$, and even uses the an additional cooling capacity generated by an ECh for technological needs resulting in a design that is more adaptable to changeable thermal loads.

The combined two-stage waste heat conversion provides an increase in the annual fuel saving by about $50 \%$ for a temperate climate as compared with typical EIAC based on an ACh.

The application of a cheap ECh as a low-temperature stage of AECh is quite reasonable in contrast to applying the additional, quite expensive, $\mathrm{ACh}$ that is able to produce chilled water of about $7^{\circ} \mathrm{C}$ and cools air lower than $15^{\circ} \mathrm{C}$. Additionally, the ECh provides cooled air of about $10^{\circ} \mathrm{C}$ and about $50 \%$ additional annual fuel saving compared with cooling the air to $15^{\circ} \mathrm{C}$ in an ACh (Figure 13). Furthermore, the ECh with refrigerant boiling at a temperature lower than $5{ }^{\circ} \mathrm{C}$ might be used to produce chilled water accumulated at decreased ambient air temperature and thermal load on the EIAC system to cover peaked cooling needs.

Author Contributions: Conceptualization, A.R., M.R., and S.F.; methodology, M.R., A.R., D.M., and S.F.; software, A.R., R.R., and S.F.; validation, A.R., M.R., and R.R.; formal analysis, M.R., A.R., D.M., and A.P.; investigation, A.R., M.R., A.P., R.R., and S.F.; resources, A.R., R.R.; data curation, A.R., M.R., and S.F.; writing—original draft preparation, M.R., A.R., and R.R.; writing—review and editing, A.R., M.R., D.M., and A.P.; visualization, M.R., A.R., and R.R.; supervision, M.R.; project administration, 
M.R.; funding acquisition, A.P. All authors have read and agreed to the published version of the manuscript.

Funding: This research received no external funding.

Institutional Review Board Statement: Not applicable.

Informed Consent Statement: Not applicable.

Data Availability Statement: Not applicable.

Conflicts of Interest: The authors declare no conflict of interest.

\section{Nomenclature and Units}

$\begin{array}{ll}\text { AC } & \text { air cooler } \\ \mathrm{AC}_{\mathrm{HT}} & \text { high-temperature air cooler } \\ \mathrm{AC}_{\mathrm{LT}} & \text { low-temperature air cooler } \\ \mathrm{ACh} & \text { absorption lithium-bromide chiller } \\ \mathrm{AECh} & \text { absorption-ejector chiller } \\ \mathrm{COP} & \text { coefficient of performance } \\ \mathrm{ECh} & \text { ejector chiller } \\ \text { EIAC } & \text { engine intake air cooling } \\ \text { HExch } & \text { heat exchangers } \\ \mathrm{O} & \text { optimal point for maximum rate of annual } \\ & \text { fuel reduction increment } \\ \mathrm{R} & \text { rational point for closed to maximum annual } \\ & \text { fuel reduction }\end{array}$

Symbols and units

B

$b_{e}$

$\mathrm{CDH}$

$\mathrm{d}_{\mathrm{amb}}$

$\mathrm{G}_{\mathrm{a}}$

$\mathrm{P}_{\mathrm{e}}$

$\mathrm{Q}_{0}$

$\mathrm{q}_{0}$

$\mathrm{t}$

$t_{\mathrm{amb}}$

$t_{\mathrm{a} 2}$

$\mathrm{t}_{0}$

$\xi$

$\varphi_{\mathrm{amb}}$

$\Delta \mathrm{b}_{\mathrm{e}}$

$\Delta \mathrm{t}$

$\sum \mathrm{B}_{10,15,20}$

$\sum \mathrm{b}_{10,15,20}$

Subscripts

$\mathrm{amb}$

$\max$

opt

rat total mass fuel consumption decrease, $\mathrm{B}=$

$\mathrm{CDH}\left(\Delta \mathrm{b}_{\mathrm{e}} / \Delta \mathrm{t}\right) \cdot \mathrm{P}_{\mathrm{e}}$

specific fuel consumption

specific heat of humid air

$\mathrm{CDH}=\Delta \mathrm{t} \cdot \tau$

ambient air absolute humidity

air mass flow rate

power output

total cooling capacity, heat flow rate

specific cooling capacity-per unit air mass

flow rate

temperature

ambient air temperature

outlet air temperature

refrigerant boiling temperature

specific heat ratio of the total heat (latent and sensible) rejected from air to its sensible heat time interval

ambient air relative humidity

specific fuel consumption decrease

air temperature decrease

annual total fuel reduction due to cooling

engine intake air to $10,15,20^{\circ} \mathrm{C}$

annual specific fuel reduction (per $1 \mathrm{~kW}$

engine power output) due to cooling engine intake air to $10,15,20^{\circ} \mathrm{C}$

air

ambient

maximum

optimal

rational $\mathrm{g}, \mathrm{kg}, \mathrm{t}$

$\mathrm{g} / \mathrm{kWh}$

$\mathrm{kJ} /(\mathrm{kg} \cdot \mathrm{K})$

$\mathrm{K} \cdot \mathrm{h}$

$\mathrm{g} / \mathrm{kg}$

$\mathrm{kg} / \mathrm{s}$

$\mathrm{kW}$

$\mathrm{kW}$

$\mathrm{kW} /(\mathrm{kg} / \mathrm{s})$ or $\mathrm{kJ} / \mathrm{kg}$

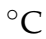

${ }^{\circ} \mathrm{C}$

${ }^{\circ} \mathrm{C}$

${ }^{\circ} \mathrm{C}$

h

$\%$

$\mathrm{g} / \mathrm{kWh}$

$\mathrm{K},{ }^{\circ} \mathrm{C}$

$\mathrm{g}, \mathrm{kg}, \mathrm{t}$ 


\section{References}

1. Zellner, S.; Burgtorf, J.; Kraft-Schäfer, D. (Eds.) Cogeneration E Trigeneration-How to Produce Energy Efficiently: A Practical Guide for Experts in Emerging and Developing Economies; Deutsche Gesellschaft für Internationale Zusammenarbeit (GIZ) GmbH: Bonn, Germany, 2016; 144p.

2. Gluesenkamp, K.; Hwang, Y.; Radermacher, R. High efficiency micro trigeneration systems. Appl. Therm. Eng. 2013, 50, 1480-1486. [CrossRef]

3. CIMAC Position Paper Gas Engine Aftertreatment Systems by CIMAC WG 17, Gas Engines, May 2017. Available online: https://www.cimac.com/cms/upload/Publication_Press/WG_Publications/CIMAC_WG17_2017_Aug_Position_Paper_ Gas_Engine_Aftertreatment_Systems.pdf (accessed on 22 June 2021).

4. Jenbacher. Available online: http://www.intma.ru/energetica/power_stations/thermal_ps_trigeneration_ru.html (accessed on 22 June 2021).

5. Rocha, M.; Andreos, R.; Simões-Moreira, J.R. Performance tests of two small trigeneration pilot plants. Appl. Therm. Eng. 2012, 41, 84-91. [CrossRef]

6. Suamir, I.N.; Tassou, S.A. Performance evaluation of integrated trigeneration and $\mathrm{CO}_{2}$ cooling systems. Appl. Therm. Eng. 2013, 50, 1487-1495. [CrossRef]

7. Rodriguez-Aumente, P.A.; Rodriguez-Hidalgo, M.C.; Nogueira, J.I.; Lecuona, A.; Venegas, M.C. District heating and cooling for business buildings in Madrid. Appl. Therm. Eng. 2013, 50, 1496-1503. [CrossRef]

8. Bassily, A.M. Performance improvements of the intercooled reheat recuperated gas-turbine cycle using absorption inlet-cooling and evaporative after-cooling. Appl. Energy 2004, 77, 249-272. [CrossRef]

9. Popli, S.; Rodgers, P.; Eveloy, V. Gas turbine efficiency enhancement using waste heat powered absorption chillers in the oil and gas industry. Appl. Therm. Eng. 2013, 50, 918-931. [CrossRef]

10. Popli, S.; Rodgers, P.; Eveloy, V. Trigeneration scheme for energy efficiency enhancement in a natural gas processing plant through turbine exhaust gas waste heat utilization. Appl. Energy 2012, 93, 623-636. [CrossRef]

11. Radchenko, A.; Trushliakov, E.; Tkachenko, V.; Portnoi, B.; Prjadko, O. Improvement of the refrigeration capacity utilizing for the ambient air conditioning system. In Lecture Notes in Mechanical Engineering, Advanced Manufacturing Processes II, Proceedings of the 2nd Grabchenko's International Conference on Advanced Manufacturing Processes (InterPartner-2020), Odessa, Ukraine, 8-11 September 2020; Tonkonogyi, V., Ivanov, V., Trojanowska, J., Oborskyi, G., Grabchenko, A., Pavlenko, I., Edl, M., Kuric, I., Dasic, P., Eds.; Springer: Cham, Switzerland, 2021; pp. 714-723. [CrossRef]

12. Radchenko, M.; Radchenko, A.; Radchenko, R.; Kantor, S.; Konovalov, D.; Kornienko, V. Rational loads of turbine inlet air absorption-ejector cooling systems. Proc. Inst. Mech. Eng. Part A J. Power Energy 2021. [CrossRef]

13. Canova, A.; Cavallero, C.; Freschi, F.; Giaccone, L.; Repetto, M.; Tartaglia, M. Optimal energy management. IEEE Ind. Appl. Mag. 2009, 15, 62-65. [CrossRef]

14. Kalhori, S.B.; Rabiei, H.; Mansoori, Z. Mashad trigeneration potential-An opportunity for $\mathrm{CO}_{2}$ abatement in Iran. Energy Conv. Manag. 2012, 60, 106-114. [CrossRef]

15. Radchenko, A.; Stachel, A.; Forduy, S.; Portnoi, B.; Rizun, O. Analysis of the efficiency of engine inlet air chilling unit with cooling towers. In Lecture Notes in Mechanical Engineering, Advances in Design, Simulation and Manufacturing III, Proceedings of the 3rd International Conference on Design, Simulation, Manufacturing: The Innovation Exchange, DSMIE-2020, Kharkiv, Ukraine, 9-12 June 2020; Ivanov, V., Pavlenko, I., Liaposhchenko, O., Machado, J., Edl, M., Eds.; Springer: Cham, Switzerland, 2020 ; pp. $322-331$. [CrossRef]

16. Freschi, F.; Giaccone, L.; Lazzeroni, P.; Repetto, M. Economic and environmental analysis of a trigeneration system for foodindustry: A case study. Appl. Energy 2013, 107, 157-172. [CrossRef]

17. Ortiga, J.; Bruno, J.C.; Coronas, A. Operational optimization of a complex trigeneration system connected to a district heating and cooling network. Appl. Therm. Eng. 2013, 50, 1536-1542. [CrossRef]

18. Chua, K.J.; Chou, S.K.; Yang, W.M.; Yan, J. Achieving better energy-efficient air conditioning-A review of technologies and strategies. Appl. Energy 2013, 104, 87-104. [CrossRef]

19. Komuro, T.; Ito, E.; Sonoda, T.; Tomita, Y.; Hidaka, K.; Shibutani, S. Power output augmentation of gas turbine combined cycle by inlet-air cooling system of chiller type under high ambient air temperature. Mitsubishi Heavy Ind. Tech. Rev. 2010, 47, 33-39.

20. Mahmoudi, S.M.; Zare, V.; Ranjbar, F.; Farshi, L.J. Energy and exergy analysis of simple and regenerative gas turbines inlet air cooling using absorption refrigeration. Appl. Sci. 2009, 9, 2399-2407. [CrossRef]

21. Al-Tahaineh, $\mathrm{H}$. Cooling of compressor air inlet of a gas turbine power plant using ammonia-water vapor absorption system. Int J. Energy Eng. 2013, 3, 267-271.

22. Andi, B.; Venkatesan, J.; Suresh, S.; Mariappan, V. Experimental analysis of triple fluid vapour absorption refrigeration system driven by electrical energy and engine waste heat. Therm. Sci. 2019, 23, 2995-3001.

23. Ghaebi, H.; Karimkashi, S.; Saidi., M.H. Integration of an absorption chiller in a total CHP site for utilizing its cooling production potential based on R-curve concept. Int. J. Refrig. 2012, 35, 1384-1392. [CrossRef]

24. Al-Ibrahim, A.M.; Varnham, A. A review of inlet air-cooling technologies for enhancing the performance of combustion turbines in Saudi Arabia. Appl. Therm. Eng. 2010, 30, 1879-1888. [CrossRef] 
25. Konovalov, D.; Kobalava, H.; Radchenko, M.; Scurtu, I.-C.; Sviridov, V. Determination of the evaporation chamber optimal length of a low-flow aerothermopressor for gas turbines. In Lecture Notes in Mechanical Engineering, Advanced Manufacturing Processes II, Proceedings of the 2nd Grabchenko's International Conference on Advanced Manufacturing Processes (InterPartner-2020), Odessa, Ukraine, 8-11 September 2020; Tonkonogyi, V., Ivanov, V., Trojanowska, J., Oborskyi, G., Grabchenko, A., Pavlenko, I., Edl, M., Kuric, I., Dasic, P., Eds.; Springer: Cham, Switzerland, 2021; pp. 654-663. [CrossRef]

26. Konovalov, D.; Kobalava, H.; Radchenko, M.; Scurtu, I.C.; Radchenko, R. Determination of hydraulic resistance of the aerothermopressor for gas turbine cyclic air cooling. In Proceedings of the TE-RE-RD 2020, E3S Web of Conferences, Constanta, Romania, 26-27 June 2020; EDP Sciences: Les Ulis, France; Volume 180. [CrossRef]

27. Lawrence, N.; Elbel, S. Experimental investigation of a two-phase ejector cycle suitable for use with low-pressure refrigerants R134a and R1234yf. Int. J. Refrig. 2014, 38, 310-322. [CrossRef]

28. Butrymowicz, D.; Gagan, J.; Śmierciew, K.; Łukaszuk, M.; Dudar, A.; Pawluczuk, A.; Łapiński, A.; Kuryłowic, A. Investigations of prototype ejection refrigeration system driven by low grade heat. In Proceedings of the HTRSE-2018, E3S Web of Conferences, Międzyzdroje, Poland, 2-5 September 2018; EDP Sciences: Les Ulis, France; Volume 70.

29. Smierciew, K.; Gagan, J.; Butrymowicz, D.; Karwacki, J. Experimental investigations of solar driven ejector air-conditioning system. Energy Build. 2014, 80, 260-267. [CrossRef]

30. Elbel, S.; Lawrence, N. Review of recent developments in advanced ejector technology. Int. J. Refrig. 2016, 62, 1-18. [CrossRef]

31. Bohdal, T.; Kuczynski, W. Boiling of R404A refrigeration medium under the conditions of periodically generated disturbances. Heat Transf. Eng. 2011, 32, 359-368. [CrossRef]

32. Kuczyski, W.; Charun, H.; Bohdal, T.; Kuczynski, W. Influence of hydrodynamic instability on the heat transfer coefficient during condensation of R134a and R404A refrigerants in pipe mini-channels. Int. J. Heat Mass Transf. 2012, 55, 1083-1094. [CrossRef]

33. Dizaji, H.S.; Hu, E.J.; Chen, L.; Pourhedayat, S. Using novel integrated Maisotsenko cooler and absorption chiller for cooling of gas turbine inlet air. Energy Convers. Manag. 2019, 195, 1067-1078. [CrossRef]

34. Zhu, G.; Chow, T.-T.; Lee, C.-K. Performance analysis of biogas-fueled Maisotsenko combustion turbine cycle. Appl. Therm. Eng. 2021, 195, 117247. [CrossRef]

35. Yanga, Y.; Wangd, B.; Zhoue, Q. Air Conditioning System Design using Free Cooling Technology and Running Mode of a Data Center in Jinan. Procedia Eng. 2017, 205, 3545-3549. [CrossRef]

36. Eidan, A.A.; Alwan, K.J. Enhancement of the Performance Characteristics for Air-Conditioning System by Using Direct Evaporative Cooling in Hot Climates. Energy Procedia 2017, 142, 3998-4003. [CrossRef]

37. Ojha, M.R.; Shukla, A.K.; Verma, P.; Kannojiya, R. Recent progress and outlook of solar adsorption refrigeration systems. Mater. Today Proc. 2020, 46, 5639-5646. [CrossRef]

38. Solovyev, A.; Pustovgar, A.; Shilova, L.; Adamtsevich, A.; Solovev, D. Simulating power efficiency of heat transfer agent cooling recirculation systems at power plants. Procedia Eng. 2016, 165, 1275-1280. [CrossRef]

39. Kornienko, V.; Radchenko, M.; Radchenko, R.; Konovalov, D.; Andreev, A.; Pyrysunko, M. Improving the efficiency of heat recovery circuits of cogeneration plants with combustion of water-fuel emulsions. Therm. Sci. 2021, 25, 791-800. [CrossRef]

40. Patel, K.R.; Dhiman, V. Research study of water-diesel emulsion as alternative fuel in diesel engine-An overview. Int. J. Latest Eng. Res. Appl. 2017, 2, 37-41.

41. Chen, H.; Pan, P.; Wang, Y.; Zhao, Q. Field study on the corrosion and ash deposition of low-temperature heating surface in a large-scale coal-fired power plant. Fuel 2017, 208, 149-159. [CrossRef]

42. Landet, R.D. PM Emissions and NOx—Reduction Due to Water in Fuel Emulsions in Marine Diesel Engines. Master's Thesis, Norwegian University of Scienceand Technology, Department of Marine Technology, Trondheim, Norway, 2010; 73p. Available online: https://ntnuopen.ntnu.no/ntnu-xmlui/bitstream/handle/11250/237793/375078_FULLTEXT01.pdf?sequence= 1\&isAllowed=yhttp:/ / hdl.handle.net/11250/237793 (accessed on 22 June 2021).

43. Patel, N.; Modi, M.; Patel, T. Investigation of diesel engine with water emulsifier-A review. Int. Res. J. Eng. Technol. 2017, 4, 879-883.

44. Miao, Y.C.; Yu, C.L.; Wang, B.H.; Chen, K. The applied research of emulsified heavy fuel oil used for the marine diesel engine. Adv. Mater. Res. 2013, 779, 469-476. [CrossRef]

45. Elberry, M.F. Performance improvement of power plants using absorption cooling system. Alex. Eng. J. 2018, 57, 2679-2686. [CrossRef]

46. Chacartegui, R.; Jiménez-Espadafor, F.; Sánchez, D.; Sánchez, T. Analysis of combustion turbine inlet air cooling systems applied to an operating cogeneration power plant. Energy Convers. Manag. 2008, 49, 2130-2141. [CrossRef]

47. Forsyth, J.L. Gas turbine inlet air chilling for LNG. IGT Int. Liq. Nat. Gas Conf. Proc. 2013, 3, 1763-1778.

48. Radchenko, A.; Trushliakov, E.; Kosowski, K.; Mikielewicz, D.; Radchenko, M. Innovative turbine intake air cooling systems and their rational designing. Energies 2020, 13, 6201. [CrossRef]

49. Marques, R.P.; Hacon, D.; Tessarollo, A.; Parise, J.A.R. Thermodynamic analysis of tri-generation systems taking into account refrigeration, heating and electricity load demands. Energy Build. 2010, 42, 2323-2330. [CrossRef]

50. Konur, O.; Saatcioglu, O.Y.; Korkmaz, S.A.; Erdogan, A.; Colpan, C.O. Heat exchanger network design of an organic Rankine cycle integrated waste heat recovery system of a marine vessel using pinch point analysis. Int. J. Energy Res. 2020, 44, 12312-12328. [CrossRef] 
51. Kuznetsov, V.; Dymo, B.; Kuznetsova, S.; Bondarenko, M. Improvement of the cargo fleet vessels power plants ecological indexes by development of the exhaust gas systems. Pol. Marit. Res. 2021, 28, 97-104. [CrossRef]

52. Radchenko, M.; Mikielewicz, D.; Tkachenko, V.; Klugmann, M.; Andreev, A. Enhancement of the operation efficiency of the transport air conditioning system. In Lecture Notes in Mechanical Engineering, Advances in Design, Simulation and Manufacturing III, Proceedings of the 3rd International Conference on Design, Simulation, Manufacturing: The Innovation Exchange, DSMIE-2020, Kharkiv, Ukraine, 9-12 June 2020; Ivanov, V., Pavlenko, I., Liaposhchenko, O., Machado, J., Edl, M., Eds.; Springer: Cham, Switzerland, 2020; pp. 332-342. [CrossRef]

53. Lee, J.H.; Yoon, H.J.; Im, P.; Song, Y.-H. Verification of energy reduction effect through control optimization of supply air temperature in VRF-OAP system. Energies 2018, 11, 49. [CrossRef]

54. Southard, L.E.; Liu, X.; Spitler, J.D. Performance of HVAC systems at ASHRAE HQ. ASHRAE J. 2014, 56, 14-24.

55. Trushliakov, E.; Radchenko, A.; Radchenko, M.; Kantor, S.; Zielikov, O. The efficiency of refrigeration capacity regulation in the ambient air conditioning systems. In Lecture Notes in Mechanical Engineering, Advances in Design, Simulation and Manufacturing III, Proceedings of the 3rd International Conference on Design, Simulation, Manufacturing: The Innovation Exchange, DSMIE-2020, Kharkiv, Ukraine, 9-12 June 2020; Ivanov, V., Pavlenko, I., Liaposhchenko, O., Machado, J., Edl, M., Eds.; Springer: Cham, Switzerland, 2020; pp. 343-353. [CrossRef]

56. Fumo, N.; Mago, P.J.; Smith, A.D. Analysis of combined cooling, heating, and power systems operating following the electric load and following the thermal load strategies with no electricity export. Proc. Inst. Mech. Eng. Part A J. Power Energy 2011, 225, 1016-1025. [CrossRef]

57. Barreto, D.; Fajardo, J.; Carrillo Caballero, G.; Cardenas Escorcia, Y. Advanced exergy and exergoeconomic analysis of a gas power system with steam injection and air cooling with a compression refrigeration machine. Energy Technol. 2021, 9, 2000993. [CrossRef]

58. Oktay, Z.; Coskun, C.; Dincer, I. A new approach for predicting cooling degree-hours and energy requirements in buildings. Energy 2011, 36, 4855-4863. [CrossRef]

59. Coskun, C.; Demiral, D.; Ertürk, M.; Oktay, Z. Modified Degree-Hour Calculation Method. In Solar Power; Rugescu, R., Ed.; InTech: Gunpo, Korea, 2012; ISBN 978-953-51-0014-0.

60. Coskun, C. A novel approach to degree-hour calculation: Indoor and outdoor reference temperature based degree-hour calculation. Energy 2010, 35, 2455-2460. [CrossRef]

61. Radchenko, A.; Mikielewicz, D.; Radchenko, M.; Forduy, S.; Rizun, O.; Khaldobin, V. Innovative combined in-cycle trigeneration technologies for food industries. In Proceedings of the V International Scientific and Technical Conference Modern Power Systems and Units (MPSU 2021), E3S Web of Conferences, Krakow, Poland, 19-21 May 2021; EDP Sciences: Les Ulis, France; Volume 323. [CrossRef]

62. Sytnikov, V. Ecological Advantages of Cogeneration; ECKO-Journal of Energy-Service Company (Ecological Systems): Kyiv, Ukraine, 2005; 7p.

63. Guentner. Available online: https://www.guentner.eu/know-how/product-calculator-gpc/gpc-software/ (accessed on 22 June 2021). 